\title{
Influence of cocoa (Theobroma cacao L.) cultivation on soil organic fractions of Dakshina Kannada district
}

\author{
N.S. VIGNESH, S.K. RAJKISHORE AND M. MAHESWARI
}

Article Chronicle :

Received:

12.02.2015;

Revised :

26.10.2015;

Accepted :

10.11.2015
ABSTRACT : The conversion of atmospheric $\mathrm{CO}_{2}$ into stable long lived carbon pools is an important phenomenon of soil carbon sequestration. Cocoa cultivation significantly increased the slow and passive carbon pools of soil. Significant increase in the organic fractions like humic acid, fulvic acids, non-humic and humin were observed in seven years cocoa cultivated soils. The organic matter fractions were significantly high during January and there after a decrease in trend were registered for all the three soils. A field study was carried out in the cocoa plantations of Moorje, Bantwal taluka, Dakshinakannada district, Karnataka. This study was carried out in five and seven years cocoa plantations in comparison with non-cocoa plantations.

HOW TO CITE THIS ARTICLE : Vignesh, N.S., Rajkishore, S.K. and Maheswari, M. (2015). Influence of cocoa (Theobroma cacao L.) cultivation on soil organic fractions of Dakshina Kannada district. Asian J. Environ. Sci.,10(2): 138-141.

Key Words :

Cocoa cultivation, Soil organic fractions, Carbon sequestration 